\title{
KOMODITAS DAN DINAMIKA PERDAGANGAN DI PAPUA MASA SEJARAH
}

\section{COMMODITIES AND TRADE DYNAMICS IN PAPUA IN THE HISTORIC PERIOD}

\author{
M. Irfan Mahmud \\ Balai Arkeologi Jayapura \\ infanarkeologi@yahoo.co.id
}

\begin{abstract}
There are only a few discussions about Papua's trading in ancient history era in the context of Nusantara. This article describes the trading and its commodities in Papua, started from a foreign source about Srivijaya c. 8th century AD. Commodities from Papua became more well-known since Java's involvement in the distribution process through "entrepot" gate Seram Sea and Banda. Majapahit 14th century's records mentioned Onim as one of the important places in Papua. This paper describes the exported and imported commodities and some sites which indicated important coastal places during the dynamic of trading in historic Papua from 14th century AD onwards. From 14th to 20th century AD, beside beautiful birds, ebony and slaves, Papua also exported nutmegs, masohi (cinamomum sp.) timbers, sandalwoods, ambers, turtle shell, shark fins, pearl shells and sea cucumbers. Some commodities were also being exported later on in 20th century $A D$ such as crocodile skins, rattan and copra. In the other hand, Papua imported many things like beads, ceramics, Timor cloth, iron tools, foods and weapons.
\end{abstract}

Keywords: Papua, Commodities, Trade, Site.

\begin{abstract}
ABSTRAK
Perbincangan mengenai Papua masih jarang memperhatikan faktor perdagangan masa sejarah kuno dalam konteks Nusantara. Tulisan ini akan menggambarkan komoditas dan perdagangan di Papua yang diawali dari berita asing yang terkait dengan Sriwijaya dalam kurun abad ke-8. Komoditas Papua semakin banyak diketahui setelah Jawa ikut memainkan peran utama distribusi lewat gerbang "entrepot" Seram Laut dan Banda. Majapahit pada abad ke-14 kemudian mencatat Onim sebagai suatu tempat penting di Papua. Dari periode abad ke-14 tulisan ini akan mengungkapkan komoditas ekspor dan impor serta beberapa situs yang menunjukkan indikasi tempat penting di pesisir dalam dinamika perdagangan di Papua masa sejarah. Sepanjang abad ke 14-20, selain burung indah kayu abnus, dan budak, Papua juga mengekspor pala, kayu masoi, cendana,damar, kulit penyu, sirip hiu, kerang mutiara dan teripang, lalu kemudian merambah komoditas kulit buaya, rotan, dan kopra terutama sejak abad ke-20. Sebaliknya, Papua mengimpor manikmanik, keramik, kain timor, peralatan besi, pangan, dan jenis senjata lainnya.
\end{abstract}

Kata kunci: Papua, Komoditas, Perdagangan, Situs

Tanggal masuk : 27 Agustus 2014

Tanggal diterima : 3 November 2014 


\section{PENDAHULUAN}

Papua dalam konteks perdagangan masa awal sejarah 栾@ merupakan halaman belakang dan 政 sekali pengetahuan mengenai Papua dan belum ada pelabuhan dagang pesisir (entrepot) yang dikenal. Pelaut Spanyol, Ynigo Ortiz de Retez, ketika pertama kali mengunjungi pantai utara Papua pada tahun 1545, juga masih buta sama sekali dan kemudian memberi nama Nueva Guinea atau Guinea Baru karena pribuminya mengingatkan dengan penduduk pantai Guinea di Afrika ${ }^{1}$ (Yuniarti 2009, 269). Bisa diduga terbatasnya pengetahuan tentang komoditas Papua sebelum abad ke-14 karena keberadaan koridor pelayaran (voyaging corridor) antara Indonesia-Filipina dan Melanesia yang telah dirintis kelompok penutur bahasa Austronesia periode 5000--1000 BP (Simanjuntak 2011, 2-3) sebelum terbit peta Spanyol semua ditempuh secara common sense.

Sejauh ini, pengetahuan tentang komoditas dan koridor maritim Papua masa sejarah masih kurang diungkap dan tidak banyak menarik perhatian peneliti sekarang dibandingkan eksotisme keragaman budaya sukunya. Karya Bachtiar (1963), Schoorl (2001), Ellen (2003), Kal Muller (2008), Reid (2011a; 2011b) dan Muridan Widjojo (2013), beberapa diantara sumber kajian terdahulu yang memberi sedikit informasi mengenai komoditas dan perdagangan Papua masa sejarah untuk melacak konteks arkeologisnya. Karya-

\footnotetext{
${ }^{1}$ Para arkeolog memperkirakan, berbagai jenis ras kulit hitam mulai berdatangan di pulau New Guinea dan Australia antara 40.000 dan 50.000 AD (lihat Muller 2008, 35; Tanudirjo 2011, 23). Kehadiran kelompok orang Negroid penutur bahasa Austronesia ditemukan jejak arkeologisnya terutama gerabah slip merah - memberi indikasi koridor mereka melintasi pulau-pulau di Asia Tenggara menuju Kepulauan Melanesia, Polinesia, dan Mikronesia serta mencapai Selandia Baru melalui pesisir utara Papua (Amal 2010, 3). Gerabah slip merah ditemukan pada situs menyebar dari wilayah Kepala Burung hingga Sentani-Jayapura (lebih lanjut lihat Mahmud 2011, 49-56).
}

karya tersebut hampir semua berlatarbelakang persoalan dan kajian komoditas dan koridor perdagangan Maluku.

Keterikatan Papua dengan koridor Maluku yang sudah terkoneksi dengan pelabuhan Jawa merupakan informasi awal mengungkapkan komoditas dan distribusinya dalam kaitan niaga Nusantara. Kontak perdagangan Papua dengan dunia luar juga diindikasikan sejumlah artefak produk impor --- seperti gerabah, keramik dan manik-manik atau mata uang--- yang jejaknya ditemukan pada sejumlah situs, diantaranya situs kawasan Sentani, Pulau Napan, Mansinam (Manokwari), Biak, Misool, Kaliraja dan Uray (Waigeo), Semenanjung Onim (Fak-Fak), serta Kampung Sran dan Namatota. Penemuan artefak impor pada sejumlah situs terkait dengan dua persoalan menarik yang akan didiskusikan dalam tulisan ini, meliputi: (1) apa komoditas ekspor dan impor Papua pada periode sejarah; (2) bagaimana dinamika perdagangan di Papua dari abad ke-14 hingga awal abad ke-20 M.

Pertukaran komoditas dan dinamika perdagangan Papua sejak sangat dipengaruhi eksistensi entrepot di Maluku. Kebangkitan Kerajaan Ternate dan Tidore pada abad ke-17 semakin memantapkan jati-dirinya dalam konteks politik, ekonomi dan militer untuk bersaing dengan para petualang/pedagang bangsa Eropa. Kedua kerajaan Maluku tersebut memiliki pandangan politik ekspansionis yang pada dasarnya didorong oleh keinginan menguasai sumberdaya alam (ekonomi/perdagangan). Ekspansi Ternate ke barat Maluku, sedangkan Tidore ke timur sampai menguasai Kepulauan Raja Ampat, kemudian Papua Daratan dan menjadikan daerahdaerah tersebut sebagai vassalnya (Amal 2010, 11). Raja Tidore Sultan Saifuddin bahkan berhasil memperoleh legitimasi yuridis dan praktis atas daerah seberang laut Tidore dengan "menukar" hak monopoli cengkeh untuk mendapatkan pengakuan dari petinggi VOC di Batavia terhadap Kepulauan Raja Ampat dan Papua Daratan pada 
tanggal 28 Maret 1667 di Batavia (Amal 2010, 177).

Berdasarkan informasi sejarah dan data arkeologis serta fokus persoalan, tulisan ini bertujuan: (1) mengungkapkan komoditas ekspor dan impor Papua dalam konteks Nusantara masa awal sejarah; (2) memberi sumbangan pada penelitian dinamika perdagangan di Papua masa sejarah di masa akan datang.

\section{BERITA ASING DAN KOMODITAS AWAL}

Sriwijaya yang bangkit sebagai "super power" Asia Tenggara abad ke-7 (Wolters 2011, 1) cukup memberi andil dalam promosi komoditas Papua pada masa awal sejarah, ditunjang letaknya di jalur ideal lalu-lintas pelayaran Jawa, India, Arab, dan Cina (Muljana 2006, 3). Pada abad ke-8, salah satu komoditas Papua telah dicatat setelah utusan raja Sriwijaya Paduka Sri Indrawarman mempersembahkan burung cenderawasih kepada kaisar Cina $^{2}$ (Bachtiar 1963, 55). Tse-fu-yuan-kuei (1005-1013 M) yang disusun Wang-ch'in-jo dan Yang I menguraikan bahwa utusan dari Sriwijaya (Fo-shih) datang ke Cina tahun 702 dan 716 M (Muljana 2006, 166). Berita Cina Tse-fu-yuan-uei dan Hsint'ang-shu juga memberitakan bahwa raja Sriwijaya Che-li-t'o-lo-pa-mo (Sri Indrawarman) pada 724 Masehi mengirim calon penggantinya bernama Kiu-mo-lo (Kumāra) sebagai utusan dengan hadiah terdiri dari dua orang cebol, seorang wanita negro (Janggi), sekelompok musikus, dan lima burung nuri (Eclectus roratus); kemudian Kaisar Cina menganugerahkan gelar tchötch'ong (jenderal) dan memperkenalkan 100 helai sutera (Kern 1929, 122; Krom 1938, 149; Majumdar 1937, 124; Muljana 2006, 166). Lalu pada tahun 728 Masehi Raja Sriwijaya kembali mengirim duta untuk bertemu Kaisar Cina dengan membawa dan

\footnotetext{
${ }^{2}$ Persembahan kepada Kaisar Cina bukan tanda tunduk, tetapi suatu bentuk pemasaran komoditas, lazimnya ditindaklanjuti oleh para saudagar masingmasing negeri (Lih. Nugroho 2011, 46-48).
}

mengenalkan burung nuri Parroquets yang memiliki bulu indah beraneka warna (Majumdar 1937, 124).

Berdasarkan berita Cina dapat diketahui dua hal penting yang pada umumnya sejarawan menghubungkan dengan komoditas Papua: tenaga kerja (wanita Janggi) dan burung nuri Parroquets atau cenderawasih yang dipersembahkan Sriwijaya untuk kaisar Cina. Sampai menjelang kedatangan Portugis di Maluku, komoditas burung indah, terutama burung nuri dan cenderawasih dari Papua merupakan produk perekonomian yang sudah dikenal dan dibawa sampai dunia luar lewat koridor Geser (Banda-Onim) atau koridor Halmahera (Ellen 2003, 64). Selain burung cenderawasih, Papua pada abad ke-9 sudah menyediakan komoditas emas dan kayu abnus atau kayu arang terutama ditujukan untuk pelabuhan India dan Sailan (Al-Haddad 1995, 156).



Gambar 1: Ragam manik-manik temuan survey di situs Indarasdi dan situs M umpendi , Biak Utara (Dok. Balar Jayapura 2010)

Meskipun komoditas Papua sudah mulai dikenal, dalam rentang periode abad ke-8-9 $\mathrm{M}$, sejauh penelitian yang dilakukan belum ditemukan suatu kompleks situs di Papua yang kaya produk mewah bernilai tinggi. Kalaupun ada barang mewah, jumlahnya sangat terbatas yang umumnya ditemukan pada situs penguburan di wilayah Kepala Burung, Biak, Pulau Napan, dan Sentani. Salah satu indikasi kontak dengan dunia luar terkait perdagangan berasal dari penemuan manik-manik dari spit 5 ekskavasi Balai Arkeologi Jayapura di situs Yamokho (Sentani) yang berada pada lapisan abad ke-8 $\mathrm{M}$ $(1253 \pm 43 \quad$ BP $)$ berdasarkan pertanggalan laboratorium The 
University of Waikato. Manik-manik batu yang ditemukan di situs Yamokho berwarna putih buram, permukaan kasar, bulat berdiameter $0,7 \mathrm{~cm}$, tebal 栾@ $0,5 \mathrm{~cm}$ dan lubang $0,2 \mathrm{~cm}$ yang dibuat dengan cara bor. Manik-manik sejenis juga ditemukan di beberapa situs di Kepala Burung dan pesisir utara Papua; dari Sorong dan Danau Ayamaru, Biak, dan Pulau Napan (Nabire) hingga kawasan Danau Sentani (Jayapura).

Hingga abad ke-10-12 Masehi, burung indah dan tenaga kerja (budak) merupakan komoditi Papua yang diekspor ke Jawa. Pengiriman tenaga kerja kasar Papua sebagai dampak kemajuan perdagangan Jawa ditorehkan pada Prasasti Garaman pada 1053 dan Prasasti Waharu IV (931) yang dikeluarkan Raja Sindok. Prasasti Waharu mencatat bahwa Kerajaan Jawa mendatangkan pekerja kasar dari Papua, Zanzibar dan Negrito untuk mengemas, membawa, dan mengirim komoditas ke sejumlah pelabuhan (Nugroho 2011, 39; 64; 71).

Dalam tahun 1200 bulu burung indah dari Papua makin dikenal sebagai komoditas yang diperdagangkan ke pulau Jawa (Flassy, 2007: 43). Seiring dengan makin dikenalnya komoditas dari Papua, pada periode yang sama ditemukan beberapa barang mewah pada situs yang mengindikasikan mulai adanya kontak terbatas dan pertukaran komoditas, berupa keramik Sung (abad ke-12-13 M) dan Yuan (Abad ke-13-14 M). Temuan keramik dalam periode ini menandai munculnya pelabuhan di pesisir baratdaya Papua. Onim menjadi pelabuhan niaga pesisir (entrepot) paling penting di Papua pada abad ke$14 \mathrm{M}$. Dari sumber sejarah diketahui bahwa kapal dagang yang singgah di Onim (Fak-Fak) seterusnya kemudian berlayar ke pulau-pulau Sulu, Magindanau, Zamboanga, dan Luzon (Al-Haddad, 1995: 32). Dari pelabuhan itulah kontak niaga efektif Papua dengan Maluku dan pedagang dari luar berkembang hingga masa kolonial. Dalam perkembangannya sejak abad pertengahan hingga masa kolonial, secara berlahan muncul pelabuhan lainnya hingga masa kolonial, diantaranya di Jazirah Onim, Kampung Kowiai (Sran), Namatota, Salawati, Waigeo, Misool, dan Mansinam.

\section{NIAGA ABAD PERTENGAHAN HINGGA KOLONIAL}

Teks klasik Nagarakertagama (1365), karya Mpu Tantular menjadi salah satu ensiklopedi toponim wawasan imperium kenusantaraan yang memberi nyala kecil dalam melihat permulaan eksistensi hubungan Papua di era keemasan dinasti Majapahit. Dalam Nagarakertagama bagian I pupuh XIV/5 disebutkan:

"muwah tang I Gurun sanūsa mangaran ri Lombok Mirah, lawan tikang I Sākşak <ādinikalun> kahajyan kabeh, muwah tanah I Bāntayan pramuk[h]a Bāntayan len Luwuk, t(ě)kěng Uda makatrayădhi nikanang sanūșăpupul. Ikang saka sanūșanūșa Mak[h]asar Butun Banggawī, Kunir G[g]aliyau mwang I Salaya Sūmba Solot Muwar, muwah tik[h]ang i Wandan Ambwan <athawa> Maloko, Wwanin, ri Seran I Timū makadi ning angeka nūșậutur".

\section{Artinya:}

"Kemudian (tersebut berikut secara berturut-turut) pulau demi pulau: Makasar, Butun, Banggawi, Kunir, Galiyau dan Salaya, Sumba, Solor, Muar (=Saparua), dan Kerajaan Wandan (=Banda), Ambwan (=Ambon), dan Maloko pula, Wwanin (=Onim), Seran, Timur. Memberi tempat pertama pada banyak sekali pulau untuk diingat"

(Nugroho 2011, 223-226; lihat pula kerajaannusantara.blogspot.com/ terjemahan Kakawin Desawanana [Nagarakertagama]).

Pengarang Cina bernama Chau Ju Kua sekitar abad ke-13 juga mencatat suatu toponim Tung-ki sebagai salah satu wilayah yang memiliki hubungan dengan Sho-p'o atau Jawa (Hirth \& Rockhill 
1911, 83). Tung-ki merupakan daerah yang tidak dapat diidentifikasi Chau Ju Kua, hanya menduga merupakan suatu nama Semenanjung di bagian timur (Hirth \& Rockhill 1911, 86). Jika toponim Wanim atau Wwanim yang disebutkan Nagarakertagama sesuai tafsiran ahli bahasa Jawa kuno merujuk Onim, suatu semenanjung yang terletak sekarang berada di Kabupaten Fak-Fak (Papua Barat), maka Tung-ki juga merujuk pada Onim (Papua). Pada saat itu, Jazirah Onim telah lama terintegrasi dengan jaringan pelayaran dan perdagangan zona Laut Jawa yang menurut catatan Kerajaan Wu dan Faxian sudah merupakan pusat perdagangan pantai (entrepot) dunia yang penting (Nugroho $2011,14 ; 51)$. Sejumlah catatan klasik juga memberi informasi adanya budak dari Papua di istana Jawa, dan kadangkadang budak-budak tersebut dihadiahkan kepada Kaisar Cina (Kamma 1953, 39).

Dengan merujuk pada berita Negarakertagama ada beberapa konteks sejarah dan arkeologi yang bisa dirujuk untuk melihat hubungan Jawa dan Papua sejak abad ke-14 ${ }^{3}$. Keramik dalam periode abad 13-15 M diangkut melalui pelabuhan Jawa yang menjadi penguasa utama jalur sumber komoditas di timur sejak abad ke-14. Sementara pedagang Arab, Cina dan India hanya sampai di pelabuhan Jawa. Sejak masa pemerintahan Raja Airlangga hingga periode keemasan Majapahit, pedagang Arab dipandang sahabat dan tidak masuk ke wilayah produsen yang sudah disatukan Jawa, demikian halnya Cina cenderung menempatkan diri sebagai tangan kedua, tidak langsung ke produsen (Nugroho 2011, 38; 67).

Sampai periode abad ke-15, Cina merupakan pasar bulu burung yang sangat potensial, tetapi cenderung dikuasai oleh pedagang Arab dari

\footnotetext{
Setelah tahun 1334, wilayah Kerajaan Majapahit bertambah luas, dari pantai barat Irian (Papua Barat) sampai Langkasuka di Semenanjung Melayu. Penguasaan Majapahit sampai Semenanjung Onim merupakan pencapaian pertumbuhan status dari desa menjadi negara yang mengusai pulau Jawa dan Nusantara. Tentang hal ini, lihat Muljana (2005, 17; 145-146); Muljana (1979, 155).
}

pelabuhan Zafar dibandingkan pelabuhan Nusantara, dimana Papua menjadi salah satu sumber komoditinya ${ }^{4}$. Pelaut dan pedagang Arab pada abad ke-15 sudah mengenal pulau Wakwak (=Fak-Fak) sebagai tempat mengumpulkan rempah-rempah (pala) dan kayu masoi serta mulai mengendalikan perdagangan setelah Majapahit pudar (Al-Haddad 1995, 32$33 ; 80 ; 87 ; 90)$. Pada periode ini, untuk menuju timur ditempuh melalui Selayar atau Sumbawa Utara ${ }^{5}$ menuju Buton (Ellen 2003, 65) sebagai pelabuhan transito Banda dan Seram Laut memasuki Papua.

Selain burung indah, budak, dan emas, jauh sebelum kedatangan Portugis tahun 1512, Papua telah menjadi salah satu sumber pemasok pala. Meskipun sebagian besar pala berasal dari Banda (Reid 2011b, 4), tetapi Banda tetap memiliki ketergantungan atas daerah sekelilinya, meliputi Seram Laut, koridor Geser dan juga rute utama pala panjang (Myristica argentea) yang bergerak dari Papua sampai memasuki jaringan dunia (Ellen 2003, 64). Bahkan pala Banda asli merupakan spesies lanjutan antara pala panjang (Myristica argentea) dan pala Onim (Myristica succedanea) yang dibawa dari Papua Barat yang didukung politik dagang Seram Laut (Ellen 2003, 64). Ketergantungan Banda terhadap daerah sekelilingnya atas komoditas pala yang terus meningkat pada abad 15-16. Kondisi ini berdampak pada peningkatan barang impor Papua yang ditunjukkan sebaran keramik Ming Swatow (abad 15-16) sebagai alat barter utama di semua situs wilayah pesisir Kepala Burung dan pesisir utara Papua (lihat tabel 3). Dari situs-situs di baratdaya, pelabuhan jazirah Onim dan Sran (Kaimana) berperan cukup besar dalam mensuplai komoditas pala "panjang" (Myristica argentea).

\footnotetext{
${ }^{4}$ Untuk hal ini bisa dicermati dari karya Al-Haddad (1995, 157-159).

Selayar dan Sumbawa merupakan pusat ekspor rempah-rempah Maluku abad pertengahan yang ditaklukkan Makassar pada abad ke-17, sekalugus mengambil peran tersebut (Reid 2011b, 107).
} 
Selain pala, komoditas kayu aikor atau aikori juga mulai dikenalkan orang Jawa dengan nama kayu mesoyi atau masoi $^{6}$ (Cryptocarya sassoia [Oken]

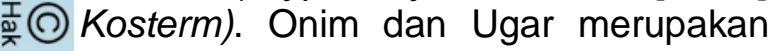
eksportir kayu masoi, sebaliknya mengimpor besi melalui Serdenha atau Banda dan Seram Laut. Lalulintas nadi Banda-Seram Laut terutama karena alasan posisi yang baik secara geografis, navigasi, dan ekonomi, dimana sebelum kedatangan Portugis telah menjadi zona perdagangan penting (Ellen 2003, 64). Sejak abad ke14, Orang Jawa dan pedagang Nusantara lainnya tampaknya mulai terpikat datang di wilayah Papua Baratdaya mencari kayu masoi (Cryptocarya sassoia [Oken]) yang bernilai tinggi atas mediasi penguasa dan pedagang Maluku (Widjojo 2013, 222). Sebaliknya, Orang Papua pesisir mulai berkenalan dengan barang mewah rumah tangga dari luar berupa keramik Sawankhalok (abad 14-15), Sukhotai (abad 14-15), dan terutama Ming Swatow (abad 15-16). Situs-situs yang menyimpan bukti kontak dagang barang mewah keramik dalam periode abad ke-14-15 $M$ tersebut antara lain: situs Kaliraja (Waigeo), Tomolol (Misool), Lilinta (Misool), Arefi (Batanta), Samate (Salawati), Semenanjung Onim (Fak-Fak), Adi Jaya (Kaimana), Kampung Sran (Kaimana), Namatota (Kaimana), serta Biak dan Napan di pesisir utara (lihat tabel 3). Berdasarkan posisi temuan ekskavasi, Situs Namatota diketahui sekurang-kurang mulai difungsikan sebagai feederport sejak abad ke 14-15 $\mathrm{M}$, mengingat $71,4 \%$ fragmen keramik kotak B10S4 spit 6 hingga spit 2 dari periode tersebut (lihat tabel 1).

${ }^{6}$ Kayu Mesoyi atau masoi adalah pohon yang berdaun bundar telur yang meruncing kea rah ujung daun. Jenis pohon masoi masih sekerabat dengan kayu manis. Orang Papua mengenal kayu ini dengan nama aikor atau aikori. Pohon ini berciri tinggi rata-rata 25 meter dengan diameter batang rata-rata $30 \mathrm{~cm}$, tebal kulit kayu $0,5 \mathrm{~cm}$.

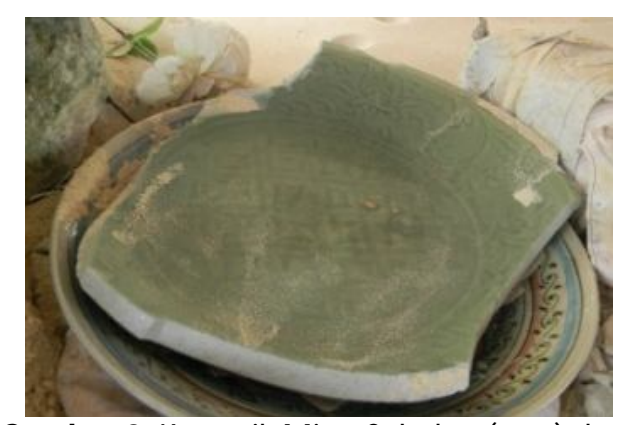

Gambar 2: Keramik M ing Celadon (atas) dan Ching (bawah) situs Namatota, Kaimana.

Kayu masoi sejenis kayu manis beraroma menyenangkan yang memiliki manfaat ganda. Bagi orang Jawa, kayu masoi biasanya digosok ke kulit untuk obat sakit perut atau penyakit yang berkaitan dengan masalah pencernaan, kosmetik, parfum, campuran pewarna batik agar permanen, penyedap rasa, obat untuk menghilangkan rasa nyeri wanita pasca melahirkan, dan campuran industri jamu yang sampai sekarang masih digunakan (Muller 2008, 85). Popularitas kayu masoi dengan multimanfaat, seiring dengan makin meningkatnya permintaan akan burung cenderawasih pada periode yang sama berdampak pada terus tumbuhnya volume perdagangan Papua dalam abad ke15-16 M. Menurut Hasan Muarif Ambary, seiring dengan meningkatnya minat pasar pada abad ke ke-15 armada raja Tidore dan Ternate melakukan pelayaran ke Timur mencari cenderawasih di Salawati (Handoko 2010, 8).

Selain cenderawasih dan kayu masoi, budak juga masih tetap menjadi komoditas yang menarik dan mudah diperoleh di Papua pada abad ke-15 Masehi. Sumber budak hampir selalu berkaitan dengan perpecahan internal, masyarakat tak bernegara atau negara kecil di timur Nusantara, seperti Papua, Bali dan Nias (Reid 2011a, 152). Masa ini pedagang dari Seram Laut memainkan peran utama dalam penjarahan dan jual-beli budak (Muller 2008, 88). Di wilayah Kepala Burung dan Kepulauan Raja Ampat sebelum datangnya pengaruh Islam, perdagangan budak cukup longgar karena sistem stratifikasi sosial mereka yang melegalkan perbudakan. 
Tabel 1. Keramik temuan ekskavasi kotak B10S4, Situs Namatota, Kaimana 2014

\begin{tabular}{|c|c|l|c|l|c|}
\hline No & Spit & Masa/Asal Produksi & Periode & Bentuk & Jumlah \\
\hline 1 & 1 & Ming & Abad ke 16-17 M & Badan piring & 2 \\
\hline 2 & 1 & Vietnam & Abad ke 14-15 M & Tepian piring & 1 \\
\hline 3 & 3 & Vietnam & Abad ke 14-15 M & Badan buli-buli & 1 \\
\hline 4 & 3 & Sukhotai & Abad ke 14-15 M & Badan mangkuk & 1 \\
\hline 5 & 4 & Swankhalok & Abad ke 14-15 M & Badan piring & 1 \\
\hline 6 & 6 & Swankhalok & Abad ke 14-15 M & Badan mangkuk & 1 \\
\hline
\end{tabular}

(Sumber: Data penelitian situs hunian di pesisir Kaimana Balai Arkeologi Jayapura 2014)

Papua tidak hanya mengekspor, tapi juga mengimpor sejumlah komoditas. Tome Pires (1513) menulis dalam Suma Oriental bahwa penduduk pulau-pulai lain (Tanimbas, Papua, dan Maluku) datang ke Banda membeli kain ${ }^{7}$ [timor] (Cortesāo 1944, 208-211; Ellen 2003, 65). Dalam catatannya, Tome Pires juga menulis bahwa selain Aru dan Kei, Papua salah satu dari tiga yang menghasilkan komoditas sagu, emas, bulu burung indah untuk diekspor ke wilayah Barat Nusantara melalui pelabuhan Banda; bulu burung lebih banyak dari Papua dan lebih dihargai dari pada yang berasal dari Aru sebagai barang dagangan yang hanya sedikit dibawa yang disebut berasal dari surga (Pires 1944, 209).

Orang Eropa telah mulai ikut memperdagangkan burung cenderawasih sejak abad ke-16 dengan menjadikan bulunya sebagai hiasan, terutama spesies Paradisea apoda, yang berarti "burung tanpa kaki dari surga". Burung cenderawasih mulai diterima orang Eropa tahun 1522 yang dikenakan para wanita Eropa dan Amerika sampai abad ke-20 (Flassy 2007, 41). Burung cenderawasih, budak, pala dan kayu masoi ditukar dengan barang impor, berupa keramik (piring,

\footnotetext{
${ }^{7}$ Chau Ju-kua (1250) mencatat bahwa dari abad ke-13 hingga abad ke-17 para pedagang Cina membawa benang dan pakaian ke berbagai pelabuhan Asia Tenggara, diantaranya Jawa; pada abad ke-16 Jawa Timur, Bali dan Sumbawa mulai menjadi pengekspor utama pakaian, diikuti Sulawesi Selatan pada abad k-17 yang bangkit sebagai eksportir pakaian terkemuka di Nusantara (Reid 2011a, 103; 107-108).
}

mangkuk, tempayan); peralatan besi ${ }^{8}$; dan manik-manik.

Di Jazirah Onim, uang Portugis diperoleh penduduk untuk diolah menjadi mas kawin yang mereka namakan wendi atau "emas negeri", yakni emas kadar rendah atau emas campuran perak yang dilebur secara tradisional (Gambar 3; Kom. Personal Abbas, 4/12/2013). Sementara di Biak, temuan spit 6 ekskavasi di situs Abib (Djami 2011, 18) menujukkan bahwa barang besi impor selain sebagai peralatan hidup yang istimewa juga dijadikan bekal kubur sebelum masyarakat setempat bisa memproduksinya. Barang impor yang diperoleh penduduk setempat kemudian meningkatkan kehormatan dan menjadi aset mahal yang melahirkan orang yang mampu mengelola dalam jaringan perdagangan lokal.

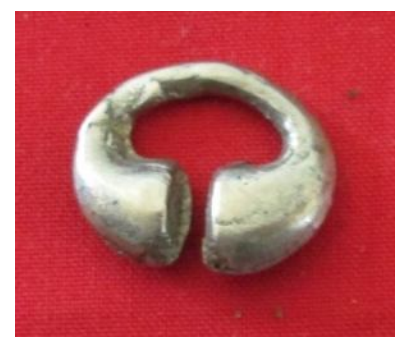

Gambar 3: Wendi warisan masyarakat di situs Patimburak

\footnotetext{
${ }^{8}$ Kerajaan Maluku sendiri sejak abad ke-16 hingga abad ke-19 mengimpor besi dan persenjataannya dari dua sumber di Sulawesi: Luwu dan Banggai (Reid 2011a, 125).
} 
Tabel 2. Komoditas dan kontak dagang abad ke-14 hingga awal abad ke-20 M

\begin{tabular}{|c|c|c|c|c|c|c|}
\hline$\omega N \quad-I \cap$ & No & $\begin{array}{c}\text { Fase } \\
\text { Perdagangan }\end{array}$ & Periode & \multicolumn{2}{|c|}{ Komoditas } & $\begin{array}{l}\text { Pedagang } \\
\text { Asing/Luar }\end{array}$ \\
\hline 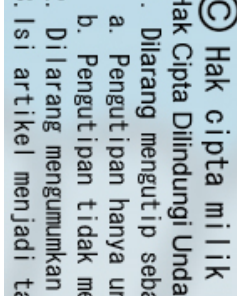 & 1 & $\begin{array}{l}\text { Fase munculnya } \\
\text { pelabuhan satelit } \\
\text { di barat-laut- } \\
\text { baratdaya Papua }\end{array}$ & $\begin{array}{l}\text { Abad ke- } \\
14--16 \mathrm{M}\end{array}$ & $\begin{array}{l}\text { - Burung indah } \\
\text { - Budak } \\
\text { - Kayu masoi } \\
\text { - Pala }\end{array}$ & $\begin{array}{l}\text { - Gerabah } \\
\text { - Keramik } \\
\text { - Manik-manik } \\
\text { - Peralatan besi } \\
\text { - Kain Timor }\end{array}$ & $\begin{array}{l}\text { - Maluku (Seram } \\
\text { Laut; Banda; } \\
\text { Bacan) } \\
\text { - Jawa } \\
\text { - Makassar } \\
\text { - Arab } \\
\text { - Eropa }\end{array}$ \\
\hline  & 2 & $\begin{array}{l}\text { Fase tumbuhnya } \\
\text { industri lokal dan } \\
\text { titik pertemuan } \\
\text { barter (central } \\
\text { place) }\end{array}$ & $\begin{array}{l}\text { Abad ke- } \\
17--18 \mathrm{M}\end{array}$ & $\begin{array}{l}\text { - Burung indah } \\
\text { - Kayu masoi } \\
\text { - Budak } \\
\text { - Pala } \\
\text { - Kerang } \\
\text { mutiara } \\
\text { - Sirip Hiu } \\
\text { - Teripang }\end{array}$ & $\begin{array}{l}\text { - Gerabah } \\
\text { - Keramik } \\
\text { - Manik-manik } \\
\text { - Peralatan besi } \\
\text { - Kain Timor } \\
\text { - Senjata } \\
\text { - Biji besi }\end{array}$ & $\begin{array}{l}\text { - Maluku } \\
\text { - Jawa } \\
\text { - Melayu } \\
\text { - Makassar } \\
\text { - Arab } \\
\text { Hadramaud } \\
\text { - Eropa }\end{array}$ \\
\hline 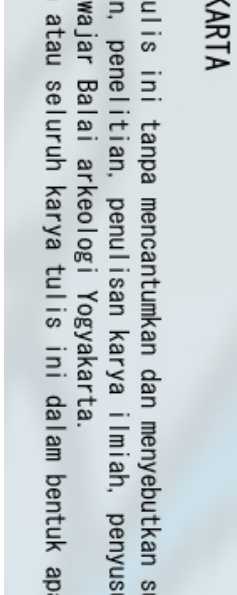 & 3 & $\begin{array}{l}\text { Fase } \\
\text { berkembangnya } \\
\text { sinergitas } \\
\text { perdagangan } \\
\text { lokal }\end{array}$ & $\begin{array}{l}\text { Abad ke- } \\
19--20 \mathrm{M}\end{array}$ & $\begin{array}{l}\text { - Burung indah } \\
\text { - Kayu masoi } \\
\text { - Budak } \\
\text { - Pala } \\
\text { - Kerang } \\
\text { mutiara } \\
\text { - Sirip Hiu } \\
\text { - Teripang } \\
\text { - Kayu cendana } \\
\text { - Damar } \\
\text { - Kulit buaya } \\
\text { - Kayu gaharu } \\
\text { - Kopra } \\
\text { - Rotan }\end{array}$ & $\begin{array}{l}\text { - Gerabah } \\
\text { - Keramik } \\
\text { - Manik-manik } \\
\text { - Peralatan besi } \\
\text { - Senjata } \\
\text { - Biji besi } \\
\text { - Kain Timor }\end{array}$ & $\begin{array}{l}\text { - Maluku } \\
\text { - Jawa } \\
\text { - Melayu } \\
\text { - Bugis } \\
\text { - Makassar } \\
\text { - Buton } \\
\text { - Nusa Tenggara } \\
\text { - Cina } \\
\text { - Eropa }\end{array}$ \\
\hline
\end{tabular}

(Sumber: Data penelitian arkeologi masa sejarah di Papua 2010-2014)

Pada abad ke 17-18 Masehi, Papua memasuki fase sinergitas lokal. Fase ini ditandai tumbuhnya industri lokal dan terbentuknya titik pertemuan barter (central place), bukan saja antara penduduk pantai Papua dan pedagang asing, melainkan juga antara masyarakat pantai dan suku-suku pedalaman. Di Misool (Raja Ampat), Kokas (Fak-Fak), dan Mimika terdapat tempat barter komoditas (central place) pada hari pasaran yang mentradisi hingga memasuki abad ke-20. Di Mimika tempat pertemuan untuk transaksi barter barang dalam bahasa suku Komoro dikenal dengan sebutan Aikwa. Di Misool (Raja Ampat), tempat pertemuan ditandai dengan tonggak-tonggak balok batu pada suatu muara sungai di situs Tomolol yang disebut penduduk setempat dengan paludi, berarti tempat sandar keranjang (noken). Di Semenanjung Onim central place (pasar barter) disebut gona atau pheh di Kampung Kayuni dengan siklus 6 harian (pasar panjang) dan pasar pendek dengan siklus 5 harian di wilayah Petuanan Fikfik, meliputi (i) Kampung Numbuktep, (ii) Pekpek, (iii) Bahbadan, (iv) Kwankwamur, (v) Mabunibuni, dan (vi) Kinam. Pasar pendek di Jazirah Onim, sekarang berlangsung setiap hari sabtu dan hanya ditemukan di Mambunibuni (Jazirah Onim).

Kelihatannya, dalam periode ini orang pantai Papua mulai ikut aktif menjadi penyalur komoditas impor dan produk lokal yang dikembangkan sesuai kondisi lingkungannya, seperti gerabah dan peralatan besi. Industri gerabah lokal berkembang antara lain di situs Abar-Sentani, Pulau Mansinam, dan 
Arguni (Semenanjung Onim). Sementara alih keterampilan mengupam besi mulai berkembang di Papua sejak Tidore memperoleh legitimasi kekuasaan dari VOC atas Papua pada abad ke-17 Masehi. Awalnya orangorang Tidore datang membawa perkakas besi ke Biak yang kemudian ditiru penduduk pulau setempat. Alih keterampilan mengupam besi dari Tidore memberi produk ekonomis baru bagi beberapa komunitas Biak, diantaranya masyarakat kampung Sowek, Bosnik, Ware, Samber (Kawer, 2010:38). Produk besi yang semula hanya monopoli pedagang Maluku, mulai juga menjadi barang barter antar orang Biak dan penduduk Papua lainnya. Orang-orang Biak pergi menjual produk besi mereka ke pulau Numfor hingga ke Woi, Pom, Serewan, Mandamen, Roon, Wasior, Onim, Namatota, Seget dan Raja Ampat; sedangkan pelayaran ke timur produk besi Biak diperdagangkan menyusuri daerah Rumi, Woda, Kerudung Kadpuri, Bonoi, Memberamo, Komamba, Armo, Sarmi, Demta, Depapre, Sentani, hingga mencapai beberapa kepulauan Pasifik (Kawer 2010, 40).

Menjelang akhir abad ke-18, industri besi Papua sudah memiliki beberapa sumbu pertumbuhan, setelah terlebih dahulu Biak berkembang pada abad ke-17. Di wilayah pesisir utara, pusat industri berada di Pulau Biak; di bagian barat berada di kepulauan Raja Ampat, dan di pesisir baratdaya Kepala Burung berkembang di Patippi (Semenanjung Onim, Fak-Fak), Kampung Sran (Kaimana). Hasil industri besi di Biak ditemukan sisa-sisanya sebagai bekal kubur yang patut diduga menyebar sampai ke Pulau Napan (Nabire). Di situs Kampung Tua Koam dan situs Mosandurei (Pulau Napan) ditemukan fragmen besi yang berasosiasi dengan fragmen keramik Ching dan Eropa (Fairyo \& Marlin Tolla 2011, 17-19). Di wilayah kepulauan Raja Ampat, indikasi industri besi ditemukan dalam ekskavasi di situs Lilinta berupa sampah biji-biji besi pada suatu struktur bekas bagian tungku peleburan biji besi tradisional. Biji-biji besi di situs Lilinta dan Biak diimpor dari Sulawesi (Luwu) sebagai sumber utama Nusantara melalui Seram Laut. Tradisi upam besi juga berkembang di Kaimana yang walaupun sisa artefaknya belum ditemukan pada situs, namun tradisi ini masih diwarisi oleh salah satu keluarga di kampung Sran sampai sekarang.

Tabel 3. Situs sumber keramik dan stoneware survei di Papua

\begin{tabular}{|c|c|c|c|c|c|c|c|c|c|c|c|c|c|c|c|c|}
\hline \multirow{2}{*}{ No } & \multirow{2}{*}{$\begin{array}{l}\text { Asal Produksi } \\
\text { (Kiln)/Periode }\end{array}$} & \multicolumn{14}{|c|}{ Lokasi Situs } & \multirow{2}{*}{ Jml } \\
\hline & & $\mathbf{A}$ & B & C & $\mathbf{D}$ & $E$ & $F$ & $\mathbf{G}$ & $\mathbf{H}$ & $\mathbf{I}$ & $\mathbf{J}$ & $\mathbf{K}$ & $\mathbf{L}$ & $\mathbf{M}$ & $\mathbf{N}$ & \\
\hline 1 & $\begin{array}{l}\text { Sung (abad ke } \\
12-13)\end{array}$ & - & - & - & - & - &  & 1 & - & - & - & - & - & - & - & 1 \\
\hline 2 & $\begin{array}{l}\text { Vietnam (abad } \\
\text { ke 14-15) }\end{array}$ & 2 & - & - & - & - & - & 5 & 1 & - & 1 & - & 3 & 3 & - & 15 \\
\hline 3 & $\begin{array}{l}\text { Yuan (abad ke } \\
13-14)\end{array}$ & 1 & - & - & - & - & - & 3 & - & - & - & - & - & 1 & - & 5 \\
\hline 4 & $\begin{array}{l}\text { Yuan (abad ke } \\
14-15)\end{array}$ & - & - & - & - & - & - & 2 & - & - & - & - & - & - & - & 2 \\
\hline 5 & $\begin{array}{l}\text { Sawankhalok } \\
\text { (abad ke 14-15) }\end{array}$ & 1 & - & - & - & - & - & - & - & - & - & - & 1 & - & - & 2 \\
\hline 6 & $\begin{array}{l}\text { Sukhotai (abad } \\
\text { ke 14-15) }\end{array}$ & - & - & - & - & - & - & 1 & - & - & 1 & - & - & 2 & - & 4 \\
\hline 7 & $\begin{array}{l}\text { Swankhalok } \\
\text { brownwere } \\
\text { (abad ke 15-16) }\end{array}$ & 1 & - & - & - & - & - & - & - & - & - & - & - & - & - & 1 \\
\hline 8 & $\begin{array}{l}\text { Ming Swatow, } \\
\text { (abad ke 15-16) }\end{array}$ & 8 & - & 15 & 1 & 2 & 2 & 12 & 1 & 1 & 4 & 1 & 22 & 12 & 7 & 88 \\
\hline 9 & $\begin{array}{l}\text { Ming, (abad ke } \\
16-17)\end{array}$ & 4 & 2 & 7 & 1 & 1 & 7 & 8 & 3 & 3 & 8 & - & - & 10 & 15 & 69 \\
\hline
\end{tabular}




\begin{tabular}{|c|c|c|c|c|c|c|c|c|c|c|c|c|c|c|c|c|c|}
\hline \multirow{9}{*}{ 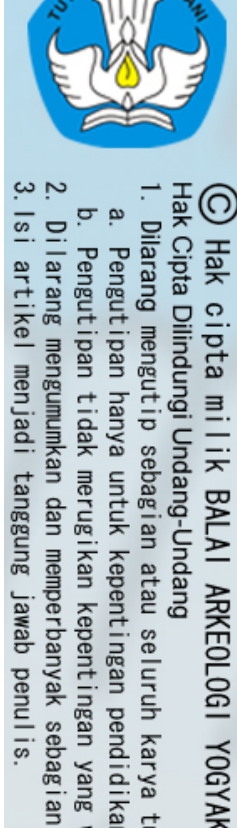 } & 10 & $\begin{array}{l}\text { Vietnam, (abad } \\
\text { ke 17-18) }\end{array}$ & - & - & - & - & 1 & - & - & - & - & & 1 & - & - & - & 2 \\
\hline & 11 & $\begin{array}{l}\text { Ching, (abad ke } \\
17-18 \text { ) }\end{array}$ & 6 & 5 & 10 & 1 & 2 & 5 & 5 & 1 & 6 & 6 & - & 29 & 16 & 12 & 104 \\
\hline & 12 & $\begin{array}{l}\text { Ching, (abad ke } \\
\text { 19-20) }\end{array}$ & 4 & - & 1 & 1 & 1 & 1 & 2 & 1 & 2 & - & - & 16 & 3 & 5 & 37 \\
\hline & 13 & $\begin{array}{l}\text { Eropa, (abad ke } \\
\text { 19-20) }\end{array}$ & 17 & - & 18 & 22 & 4 & 4 & 11 & 6 & 8 & 5 & 3 & 5 & 1 & 35 & 139 \\
\hline & 14 & $\begin{array}{l}\text { Stonewere, } \\
\text { (abad ke 19-20) }\end{array}$ & - & 1 & - & 1 & - & - & - & - & - & - & - & - & 1 & - & 3 \\
\hline & 15 & $\begin{array}{l}\text { Jepang , (abad } \\
\text { ke 19-20) }\end{array}$ & - & - & 1 & - & - & - & - & - & - & - & - & - & - & - & 1 \\
\hline & 16 & $\begin{array}{l}\text { Modern, (abad } \\
\text { ke-20) }\end{array}$ & - & - & 13 & 2 & - & - & - & - & - & - & - & - & - & - & 15 \\
\hline & & TOTAL & 44 & 8 & 65 & 29 & 11 & 19 & 50 & 13 & 20 & 25 & 5 & 76 & 49 & 74 & 488 \\
\hline & \multicolumn{17}{|c|}{$\begin{array}{l}\text { (Sumber: Penelitian arkeologi di Papua tahun 2010-2014) } \\
\text { Keterangan:(A) Situs Kaliraja; (B) Saonek; (C) Pulau Urai; (D) Lilinta; (E) Kllimala; (F) Samate; (G) Namatota; } \\
\text { (H) Biak; (I) Mansinam; (J) Batanta; (K) Kaimana; (L) Patippi Pasir (Onim); (M) Kampung Tua } \\
\text { Furir (Onim); (N) Situs M osandurei (Napan). }\end{array}$} \\
\hline
\end{tabular}

Sepanjang periode abad ke-18, pedagang dari Maluku, Jawa, BugisMakassar, Arab (Hadramaud), dan Eropa mencoba terus mengeksplorasi komoditas unggul lainnya di Papua yang sudah dikenal sangat laku di pasar dunia sejak abad pertengahan. Bukti eksistensi orang Bugis ditunjukkan temuan makam kuno komunitas tersebut di situs Lilinta dan Waigama, sementara kehadiran saudagar Arab ditemukan di situs Usaha Jaya, Misool (Gambar 4-5). Pengaruh Jawa dan Melayu Islam di lain pihak diantaranya dapat ditunjukkan dari atap tumpang dan arsitektur masjid di situs Patimburak (Fak-Fak) yang dari perspektif pola dasarnya mengingatkan kita pada masjid dan keraton Kesultanan Deli (Melayu). Kehadiran berbagai etnis di Papua pada masa itu dirangsang komoditi hutan berupa pala (Myristica fragrans), kayu gaharu ${ }^{9}$ (Aquilaria moluccensi), kayu cendana (Santalum album), dan damar (Agathis dammara). Pala (Myristica fragrans) pada periode

\footnotetext{
9 Kayu gaharu dalam konteks perdagangan dunia tidak pernah menjadi barang dagangan terkenal, karena tumbuh luas di Asia Tenggara. Sejak awal masehi, getah gaharu bagi pemeluk Tao dipakai untuk memperkuat tubuh (suplement) saat berpuasa, dan dipercaya dapat mamanjangkan umur orang yang sedang sakit, obat kudis, luka parah, botak serta gatal-gatal. Pengobatan dilakukan dengan pengasapan. Bagi orang Cina, gaharu dipercaya dapat menenangkan 5 organ dalam (jantung, hati, limpa, paru-paru, dan ginjal) serta dapat menghilangkan (Wolters 2011, 63-104)
}

ini mencapai bobot permintaan tertinggi sepanjang sejarah, sehingga menjadi salah satu produk unggulan.

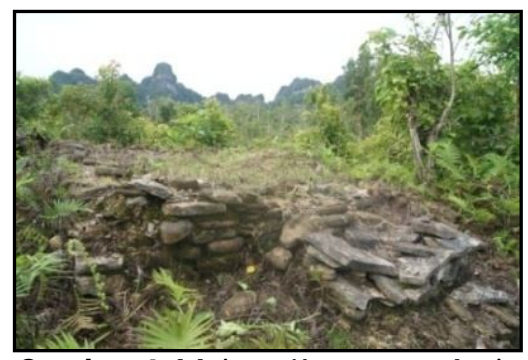

Gambar 4: M akam Keturunan Arab (Hadramaud) di situs Usaha Jaya, Misool .

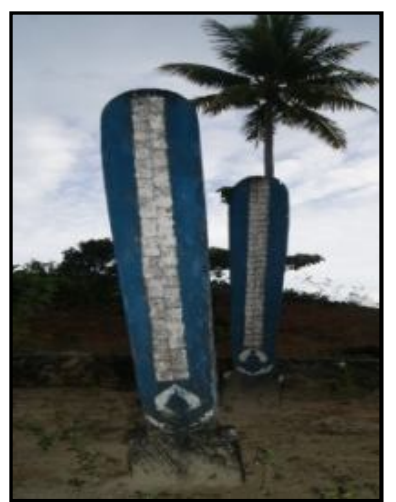

Gambar 5: Makam migran Bugis bernama Solehuddin Waju di situs Lilinta, M isool, Raja Ampat. Fak-Fak, Papua Barat (Dok. Balar Jayapura 2012) 
Dari laut Papua, para pedagang memburu kulit penyu (Dermochelys coriacea), sirip hiu (Trinedon obesus), kerang mutiara (Pinctada maxima), dan teripang (Holothuroidea) untuk jaringan pasar dunia. Sisa-sisa perburuan komoditas laut ditemukan sisa artefaknya pada sejumlah situs di Misool, Kampung Sran, Namatota, Patippi (Onim) dan Kampung Tua Furir (gambar 5). Mitra utama perdagangan komoditas laut di Papua, terutama orang Makassar yang datang sebagai pedagang perantara dengan membawa keramik, peralatan besi, dan kain (Mahmud 2013a, 44). Pencarian komoditas laut di Papua terkait dengan meningkatnya permintaan pedagang Cina sejak abad ke-17 di pelabuhan Makassar $^{10}$ atas kulit penyu, kerang mutiara, sirip hiu, dan teripang yang mereka sebut hai som yang dimanfaatkan sebagai bahan penyedap sup (Nasruddin 2002, 125).

Hasil penelitian arkeologi pada situs-situs di Papua menunjukkan masih rendahnya volume perdagangan dibandingkan kawasan Nusantara dalam periode yang sama, berupa: keramik, gerabah, manik-manik, biji besi, senjata (meriam, badik/keris), dan kain timor, serta barang tembaga untuk kepentingan khusus. Satu-satunya barang tembaga dari abad ke-18 yang ditemukan di situs pulau Mansinam berupa cawan buatan pabrik Meuuws \& Zoom Den Haag tahun 1775, berukuran tinggi $14 \mathrm{~cm}$, diameter dasar $11 \mathrm{~cm}$, dan dimeter mulut $9 \mathrm{~cm}$. Cawan tembaga di situs Mansinam yang dibawa oleh misionaris berfungsi untuk ibadah perjamuan kudus gereja. Keterbatasan komoditas yang diimpor Papua berkaitan dengan masih rendahnya daya beli, kebutuhan, populasi penduduk yang menghuni pulau ini jarang dan terpencar-pencar dalam jarak jauh yang membutuhkan biaya mahal dalam pengembangan "economies of

\footnotetext{
${ }^{10}$ Rute pelayaran ke Maluku sudah dikenal pelaut Bugis-Makassar sejak masa awal pertumbuhan dinasti kalasik sebagaimana Kitab Klasik Lagaligo sudah menyebuttoponim Ternate sebagai pulau yang memiliki hubungan sekitar abad ke-9-10 Masehi (Mahmud 2013b, 41)
}

scale" (keuntungan yang diperoleh dan skala produksi yang besar).



Gambar 6: Sisa sampah kulit kerang mutiara yang ditemukan pada situs Kampung Furir, Fak-Fak, Papua Barat (Dok. Balar Jayapura, 2012)

Ekskavasi di situs Kampung Amoi, Distrik Warsa pada kotak S3B1 ditemukan 3 buah manik-manik yang berada pada spit 2 lapisan yang sama dengan keramik Ching (Mas'ud 2012, 12-13). Penemuan manic-manik di Kampung Amoi menegaskan bahwa impor dan penggunaan manik-manik di Papua terus berlangsung sepanjang abad ke-18-19 M. Temuan arkeologi tahun 2011 di Biak pada Kotak TP.1 situs Arombo spit 1 (Djami 2011, 15), menunjukkan bahwa selain sebagai perhiasan dan alat tukar, manik-manik juga tetap dipakai untuk bekal kubur kalangan masyarakat Papua pesisir sampai abad ke-19 sebelum mendapat sentuhan misi agama Kristen.

Pada abad ke-19, perburuan burung Cenderawasih di wilayah Papua mencapai puncaknya, terutama dilakukan suku-suku pedalaman. Perburuan besar-besaran suku pedalaman akan burung cenderawasih terkait dengan sangat meningkatnya permintaan pasar Eropa untuk memenuhi kebutuhan perkembangan dunia mode (Muller 2008, 93). Suku Kaipuri dan Sowari di pedalaman misalnya, semakin aktif menukar burung cenderawasih dengan barang yang dibawa penduduk dari Teluk Wandamen dan Teluk Cenderawasih berupa keramik, kotak daun pandan, buah pinang hutan, ikan kering dan peralatan besi. Perdagangan barter semacam ini juga menjadi fenomena umum bagi suku-suku yang bermukim di Onim (Fak- 
Fak), Mimika, dan Sorong (orang Maybrat) (Suroto 2010, 18). Ekspedisi pencarian burung-burung indah dan komoditas lokal lainnya oleh pedagang 栾@ Ternate sampai ke Pulau Metu Debi dengan menukar senjata. Di Merauke tahun 1914 pedagang Jawa, Nusa Tenggara, Maluku, dan Cina juga melakukan barter burung cenderawasih dengan peralatan besi. Mereka berburu cenderawasih untuk ditukar dengan komoditas lainnya dari luar, terutama pangan, keramik dan manik-manik dan kain timor. Khusus untuk kain timor, perdagangannya hanya meliputi wilayah Kepala Burung, Sorong, Maybrat, Inanwatan.

Selain burung indah, sampai akhir abad ke-19 Papua masih identik dengan sumber budak belian yang sudah berkembang sebelumnya. Budak merupakan hal yang paling menarik dan mudah diperoleh di Papua sampai abad ke-19. Pada abad ke-19, orang Biak mengambil alih peran orang Seram Laut sebagai penyedia budak belian. Dahulu selalu ada ekspedisi raak yang bermakna perang, perompakan dan penjarahan, terutama pada perburuan budak yang sangat menguntungkan. Aksi-aksi penjarahan dilakukan orang Biak dari Raja-Ampat sampai timur laut Jawa. Pemimpinnya disebut mambri, yang berarti pemimpin di laut, tetapi sekembali di daratan pada waktu damai tidak mempunyai kekuasaan apa-apa (Schoorl 2001, 457).

Selain budak, Papua juga menyediakan berbagai sumberdaya yang diperjualbelikan di pasar lokal dan regional. Komoditas dagang yang lazim meliputi: kayu masoi, pala, teripang, dan menjadi makin bervariasi sejak pertengahan abad ke-20 dengan meningkatnya permintaan damar (Agathis dammara [Lamb.) dan rotan (Daemonorops rubra). Di wilayah Kepala Burung, damar, dan roton dipasok sukusuku asli kepada tengkulak Cina dan Bugis yang datang dari Sorong dan Bintuni (Sanggenafa dan Koentjaraningrat 1992, 159). Ekspansi dagang Cina ke Papua telah menciptakan kantong pemukiman Pecinan di Pulau Doom (Sorong),
Kaimana, dan Serui. Komoditas hutan yang dipasok suku-suku pedalaman kemudian ditukar dengan gerabah, manic-manik, keramik, dan kain timor. Dalam kontak di wilayah Kepala Burung, perdagangan komoditas hutan yang ditukar dengan manik-manik, gerabah, dan kain timor melalui dua koridor: (1) Koridor utara dengan central place utama Pulau Waigeo memasuki daerah Makbon menuju Karondori (Moi Karon) dan terakhir Ambarbaken; (2) Koridor Onim menuju Bomberai, Kokas, Babo, dan Teluk Bintuni, hingga sampai memasuki dataran Tanah Maladun.

Awal abad ke-20, suku Bauzi yang menghuni DAS Sungai Membramo juga mulai ikut dalam menyediakan komoditas dagang. Kulit buaya merupakan komoditas andalan suku Bauzi dalam melakukan kontak dagang dengan pihak luar. Barter diantara penduduk pedalaman dan pantai semakin meluas sampai pertengahan abad ke-20, seperti kelompok dari Citak, datang ke Kepi (Merauke) untuk menukarkan kulit buaya dengan pisau, kapak, makanan, dan barang-barang lain (Schoorl 2001, 339). Dinamika perdagangan yang bertambah meluas cakupannya, semakin memberi banyak pengetahuan tentang kekayaan komoditas Papua kepada dunia luar.

\section{PENUTUP}

Komoditas dari Papua yang mulamula dikenal dunia luar terkait dengan burung indah dan tenaga kerja (budak). Komoditas burung indah Papua didistribusikan keluar Papua lewat Bacan, Seram Laut, dan Banda. Komoditas burung indah dari Papua diperjualbelikan oleh pedagang Maluku, Melayu, dan Jawa, diikuti pedagang Arab dan selanjutnya Eropa. Selain burung indah, budak dan kayu abnus pada masa-masa awal kontak dengan dunia luar, Papua lewat pelabuhan Banda dan Seram Laut juga mensuplai pala, kayu masoi, cendana, damar, kulit penyu, sirip hiu, kerang mutiara dan teripang. Memasuki abad ke-20, Papua juga menyediakan komoditas kulit buaya, kopra, dan rotan. Sebaliknya, 
Papua mengimpor gerabah, manikmanik, keramik, kain timor, kebutuhan pangan, bahan dan peralatan besi, serta berbagai jenis senjata lainnya. Peralatan besi setelah abad 17-18 $M$ telah diproduksi secara terbatas di Biak, Patippi (Onim), dan Kampung Sran (Kowiai, Kaimana). Selain peralatan besi, juga ditemukan industri gerabah yang sudah tumbuh jauh sebelumnya di Arguni (Fak-Fak), Pulau Mansinam, dan Abar (Sentani-Jayapura).

Dalam keseluruhan gambaran data arkeologi dan sejarah, dapat disimpulkan bahwa komoditas Papua mulai dikenalkan secara resmi sejak abad ke-8 M ketika Kerajaan Sriwijaya di Sumatera mempersembahkan burung indah kepada kaisar Cina. Dari periode abad ke 9-11 $M$, burung indah merupakan komoditas utama selain pala dan tenaga kerja (budak). Keberadaan tenaga kerja kasar (budak) dari Papua di pelabuhan Jawa dicatat pada prasasti Waharu IV (abad ke-10) dan Garaman (abad ke-11). Sepanjang sejarah perdagangan di Papua, komoditas burung cenderawasih menjadi produk perekonomian khas yang dicari dan terus menggoda hasrat perburuan sepanjang abad ke-14 hingga awal abad ke-20. Barang impor yang ditemukan dalam periode abad ke 8-13 $M$ hanya berupa manik-manik di situs Yemokho.

Sepanjang abad ke-14-16 M komoditas kayu masoi mulai dicari pedagang dari Jawa, selain pala dan burung indah. Meskipun demikian, peran entrepot Banda dan Seram Laut sebagai pintu gerbang masih dominan pada fase ini, kemudian ditopang kebangkitan Jazirah Onim (Fak-Fak) sebagaimana dicatat Nagarakrtagama (Wwanim) dan Berita Cina (Tung-kı) serta dibuktikan dengan indikasi keramik periode ini, seperti dari situs Patippi, Ugar, dan Kampung Tua Furir. Bangsa Eropa baru mulai ikut terlibat dalam perdagangan komoditas burung cenderawasih dan pala Onim sejak abad ke-16.

Periode selanjutnya, abad 17-18 Masehi ditandai dengan meningkatnya permintaan pala di pasar dunia sehingga menjadikannya komoditas unggul yang nilainya lebih dari emas pada masanya. Pada fase ketiga (abad ke-17-18 M), peran pedagang Jawa mulai digantikan oleh saudagar Bugis-Makassar, selain Arab (Hadramaud), Melayu, dan Eropa. Makam kuno Bugis-Makassar di situs Lilinta dan makam kuno Saudagar Arab di situs Usaha Jaya (Misool) menjadi bukti eksistensi kedua komonitas di wilayah Kepala Burung. Orang-orang Makassar sangat dominan dalam perdagangan komoditas laut Papua yang sangat dibutuhkan dan dinantikan pedagang Cina di entrepot Somba Opu, berupa kerang mutiara, Sirip Hiu, Teripang. Selain komoditas laut Papua, pedagang Maluku, Bugis-Makassar, Arab, Jawa dan Eropa juga mencari komoditas hutan dan merangsang koneksitas dagang antara penduduk pantai dan pedalaman serta secara tidak langsung mendorong munculnya central place, seperti di Jazirah Onim (gona; pheh), situs Tomolol (paludi), dan Timika (aikwa).

Pada abad ke-19-20 M perdagangan di Papua ditandai terbentuk sinergitas perdagangan lokal. Sinergitas perdagangan lokal melibatkan penduduk setempat dalam bentuk kontak niaga antar-suku pantai dan pedalaman. Perburuan komoditas damar dan rotan oleh tengkulak Bugis dan Cina yang sudah terkoneksi dengan pedalaman tumbuh pada fase ini. Peningkatan aktivitas dagang Cina kemudian melahirkan beberapa kantong pemukiman Pecinan di Papua yang tetap terbina sampai sekarang, diantaranya di situs Pulau Doom (Sorong), Kaimana, dan Serui. 


\section{DAFTAR PUSTAKA}

Al-Haddad, Al-Habib Alwi bin Thahir. 1995. Sejarah Masuknya Islam di Timur Jauh. Jakarta: Lentera Basritama.

Amal, M. Adnan. 2010. Kepulauan Rempah-Rempah: Perjalanan Sejarah Maluku Utara 1250-1950. Jakarta: Kepustakaan Populer Gramedia.

Bachtiar, Harsja W. 1963. "Sejarah Irian Barat" dalam Koentjaraningrat dan Harsja W. Bachtiar (ed.) Penduduk Irian Barat. Jakarta: P.T. Penerbitan Universitas. HIm. 5594.

Cortesāo. 1944. "The Suma Oriental of Tome Pires, an Account of the East from the Red Sea to China written in Malacca in 1512-1515, and the Book of Francisco Rodriguez, Pilot Major of Armada that Discovered Banda and the Moluccas". Hakluyt Society, $2^{\text {nd }}$ Series, Vol. 89.

Djami, Erlin Novita Idje. 2011. "Penelitian Arkeologi di Kabupaten Biak Numfor: Manusia Berpenutur Austronsia”. Laporan Penelitian Arkeologi. Jayapura: Balai Arkeologi Jayapura.

Ellen, R.F. 2003. On the Edge of the Banda Zone: Past and Present in the Social Organization. Engelska: University of Hawaii Press.

Fairyo, Klementin dan Marlin Tolla. 2011. "Penelitian Arkeologi di Distrik Napan, Kabupaten Nabire, Propinsi Papua". Laporan Penelitian Arkeologi. Jayapura: Balai Arkeologi Jayapura.

Flassy, Don A.L. 2007. Fauna Tanah Kita. Saduran dari Karya Dr.L.D. Brongersma, Dieren van Nieuw-Guinea. Jakarta: Balai Pustaka.

Handoko, Wuri. 2010. "Gerak Niaga Maluku - Papua: Zona Ekonomi dan Kekuasaan Islam" dalam Jurnal PAPUA Vol. 2, No. 1, Juni 2010. HIm. 1-13.

Hirth, Friedrich \& W.W. Rockhill. 1911. Chau Ju-kua: His Work on the Chinese and Arab Trade in the Twelfth and Thirteenth Centuries, entitled Chu-fan-chï. (Translated from the Chinese and Annotated). St. Petersburg: Imperial Academy of Sciences.

Kamma, F.C. 1953. Kruis en Korwar: Een Honderdjarig Vraagstuk op Nieuw Guinea. Den Haag: J.N. Voorhoeve

Kawer, Sonya. 2010. "Perdagangan Besi pada Masyarakat Biak Numfor" dalam Jurnal PAPUA Vol. 2, No 1, Juni 2010. HIm. 35-43.

Kern, H. 1929. Hindoe Javaanse Geschiedenis. Netherlands: s'Gravenhage.

Krom, N.J. 1938. "Het Hindoe-tijdperk" dalam F.W. Stapel: Geschiedenis van Nederlandsch Indië Vol. I. Amsterdam: N.V.U.U. Joost van den Vondel.

Mahmud, M. Irfan. 2011. "Jejak Budaya Austronesia, Melanesia, dan Tradisi Prasejarah Berlanjut di Papua" dalam M. Irfan Mahmud dan Erlin Novita Idje Djami (ed.) Austronesia dan Melanesia di Nusantara. Yogyakarta: Penerbit Ombak. HIm. 4374. 
2013a. "Pelayaran dan Perdagangan Abad XVII-XIX Bugis-Makassar ke Papua" dalam Jurnal PAPUA Vol. V, No. 1, Juni 2013. Hlm. 37-57.

2013b. "Akulturasi Budaya Lokal dan Konsepsi Islam di Situs Kaliraja, Raja Ampat" dalam Jurnal PAPUA Vol. V, No. 1, Juni 2013. HIm. 50-75.

Majumdar, R.C. 1937. Ancient Indian Colonies in the Far East Vol. II, Suvarnadvipa Part I-Political History. Dacca: Asutosh Press

Mas'ud, Zubair. 2012. "Ekskavasi situs Kampung Tua Warsa, Kabupaten Biak Numfor". Laporan Penelitian Arkeologi. Jayapura: Balai Arkeologi Jayapura.

Muller. Kal. 2008. Mengenal Papua. Daisy World Books.

Muljana, Slamet. 1953. Prapantja: Nagarakretagama (Terjemahan). Djakarta: N.V. Siliwangi.

Karya Aksara.

1979. Nagarakretagama dan Tafsir Sejarahnya. Jakarta: Bhratara Yogyakarta: LKiS.

2006. Sriwijaya. Yogyakarta: PT. LKiS Pelangi Aksara.

Nasruddin. 2002. "Ekspedisi Jejak Kehadiran Pelaut Makassar di Pesisir Pantai Utara Australia, Abad XVII" dalam M. Irfan Mahmud dkk. (ed.) Tradisi, Jaringan Maritim, dan Sejarah-Budaya: Perspektif Etnoarkeologi-Arkeologi Sejarah. Makassar: Lembaga Penerbitan Universitas Hasanuddin. HIm. 117-130.

Nugroho, Irawan Djoko. 2011. Majapahit Peradaban Maritim (Ketika Nusantara Menjadi Pengendali Pelabuhan Dunia). Jakarta: Yayasan Suluh Nuswantara Bakti.

Reid, Anthony. 2011a. Asia Tenggara dalam Kurun Niaga 1450-1680 Jilid I: Tanah di Bawah Angin. Jakarta: Yayasan Obor Indonesia

2011b. Asia Tenggara dalam Kurun Niaga 1450-1680 Jilid II: Jaringan Perdagangan Dunia. Jakarta: Yayasan Obor Indonesia

Sanggenafa, N dan Koentjaraningrat. 1992. "Pertukaran Kain Timur di Daerah Kepala Burung" dalam Koentjaraningrat, dkk. (ed.) Irian Jaya: Membangun Masyarakat Majemuk. Jakarta: Djambatan. HIm. 156-172.

Schoorl, P. 2001. Belanda di Irian Jaya: Amtenar di Masa Penuh Gejolak 1945-1962. Jakarta: Penerbit Garba Budaya.

Simanjuntak. Truman. 2011. "Austronesia Prasejarah di Indonesia" dalam M. Irfan Mahmud dan Erlin Novita Idje Djami (ed.) Austronesia dan Melanesia di Nusantara: Mengungkap Asal-Usul dan Jati-Diri dari Temuan Arkeologis. Yogyakarta: Penerbit Ombak. HIm. 1-21.

Suroto, Hari. 2010. "Perburuan dan Perdagangan Burung Cenderawasih di Papua" dalam Jurnal PAPUA Vol. 2, No 1, Juni 2010. HIm. 15-21. 
Tanudirjo, Daud Aris. 2011. "Interaksi Austronesia - Melanesia, Kajian Interpretasi Teoritis" dalam M. Irfan Mahmud dan Erlin Novita Idje Djami (ed.) Austronesia dan Melanesia di Nusantara: Mengungkap Asal-Usul dan Jati-Diri dari Temuan Arkeologis. Yogyakarta: Penerbit Ombak. HIm. 23-42.

Widjojo, Muridan. 2013. Pemberontakan Nuku: Persekutuan Lintas Budaya di MalukuPapua Sekitar 1780-1810. Depok: Komunitas Bambu.

Wolters, O.W. 2011. Kemaharajaan Maritim Sriwijaya dan Perniagaan Dunia Abad IIIVII. Depok: Komunitas Bambu

Yuniarti, Fandri (ed.). 2009. Ekspedisi Tanah Papua, Laporan Jurnalis Kompas. Jakarta: Penerbit Buku Kompas 